\title{
Many Ways to Rome: The LARP's Development of Technical Tools to Approach Resilience and Resistance within the Roman Empire
}

\author{
By Vagner Carvalheiro Porto ${ }^{*}$, Marcio Teixeira-Bastos ${ }^{\dagger}$ \\ \& Alex da Silva Martire
}

The Laboratory for Roman Provincial Archaeology (LARP), a thematic Lab of the Museum of Archaeology and Ethnology of the University of São Paulo, Brazil, aims to conduct research on the Roman presence in the areas of dominance in the Mediterranean sphere of influence and beyond. Cultural transformation and its correlates in material culture are investigated through analyses that assess the changes in its many aspects, given the variability of the contexts of societies under Roman imperial power. Thus, this paper seeks to propose a more flexible and multilateral reading between Rome and its provinces, where the forms of contact among Rome and the provinces had, in reality, a two-way relationship that should be considered not to be conflicting, but converging. In essence, we highlight the performance of provincial elites facing Roman domination. One of LARP's main instruments of action is the application of new technologies that act through images, two-dimensional or three-dimensional, interactive or passive. Virtual reality, also a means of scientific visualization, can be used for data analysis both in three-dimensional environments as well as in interactive exemplification that assist in the cognitive process of researchers, teachers and/or students.

Keywords: Roman Empire, Roman Provinces. Virtual Reality, Cyber-Archaeology.

\section{Introduction}

The research conducted at the Laboratory for Roman Archaeology (LARPUSP), located at the University of Sao Paulo's Museum of Archaeology and Ethnology, Brazil, resulted in a success extension program in which include educational actions, archaeological research, technology and development of new products and discussions, unprecedented at the national level. Under the flagship idea that of perceiving the relations with Rome not as an unthinking acceptance of a cultural imposition by Rome. But rather than as multi-way relationship where the respect of certain nuances (e.g. resilience and resistance)

\footnotetext{
*Assistant Professor of Classical Archaeology, Museum of Archaeology and Ethnology. University of São Paulo, Brazil. Co-coordinator of the Laboratory for Roman Provincial Archaeology (LARP).

†Postdoctoral Researcher of Classical Archaeology, State University of São Paulo, History Department, São Paulo, Brazil. Researcher of the Laboratory for Roman Provincial Archaeology (LARP).

* PhD in Classical Archaeology, Museum of Archaeology and Ethnology. University of São Paulo, Brazil. Researcher of the Laboratory for Roman Provincial Archaeology (LARP).
} 
of each city and people under domination play a part. The main idea is to provide a better understanding of the material culture and past agency of those peoples who also formed part of the Roman Empire.

In order to approach Ancient History and Archaeology in Brazil, these innovative projects (more digital, intuitive, collecting geo-data of provinces and regions of Roman Empire) have been widely disseminated to the LusoPortuguese speakers around the World and in the Brazilian community. The digital platforms such as LARP-Sig Web; Roma 360 (Figure 1); Domus Romana; Domus Redux, Roma Touch, Domus and Rome with Augmented Reality, and recently a game named "O último banquete em Herculano" (The last banquet in Herculaneum) are new tools that have demonstrated the ability of the a look at the two elements (resilience and resistance) of each Roman city - not noticed or weighed often enough as people learn archeological sites. It is important to highlight at this point that it helps to create a better sense of space, which is pre-designed and materialized. Some of the projects are versions of mobile applications - accessed by smartphones and tablets - and are the first Brazilian cyber archeological projects to win versions for the Android platform, reinforcing the pioneering and diffusing nature of knowledge that is in the heart of LARP ${ }^{11}$.

Figure 1. Roma 360 - Screenshot

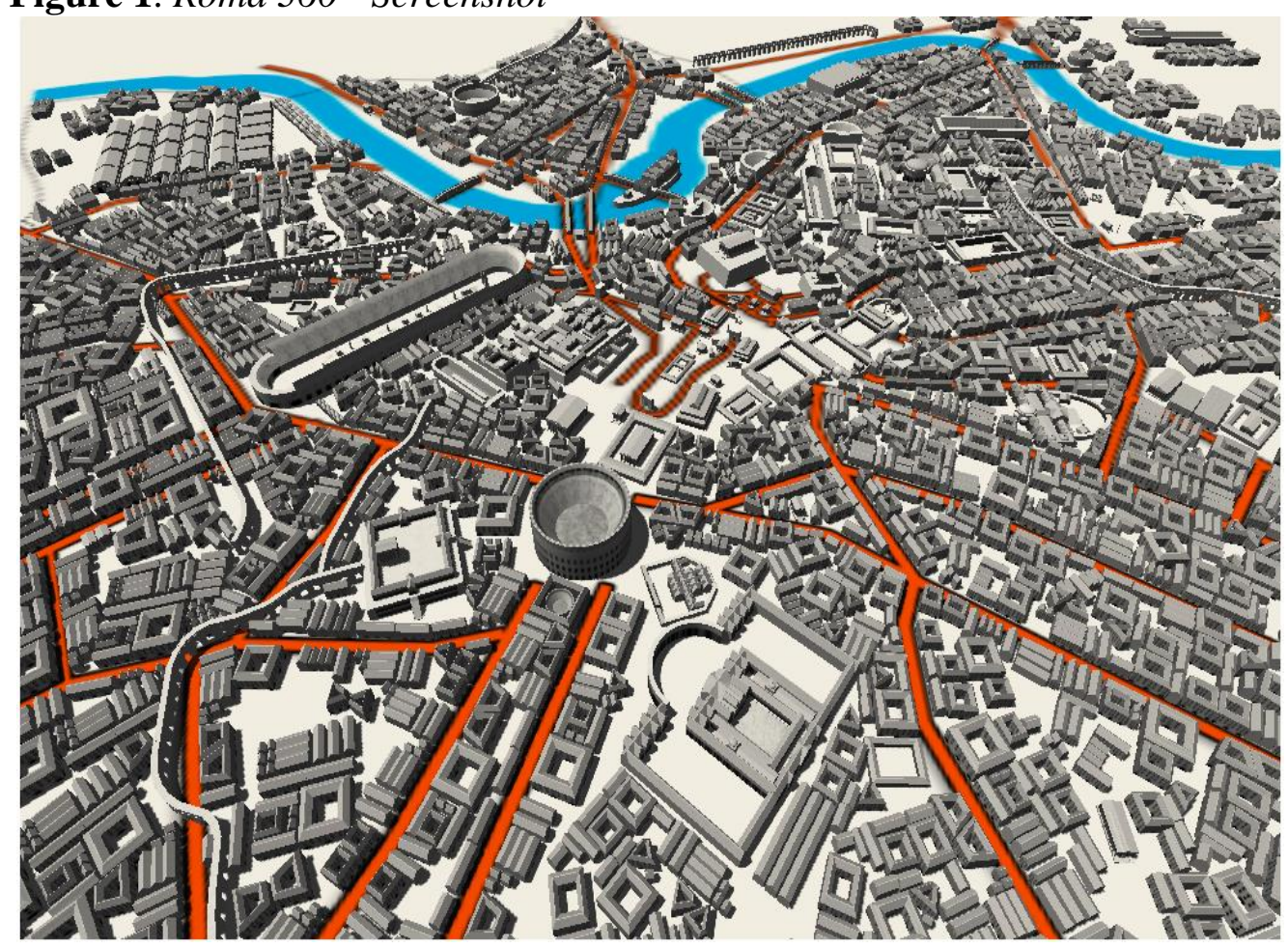

${ }^{1}$ http://www.larp.mae.usp.br. 
In order to articulate in what degree material culture influenced the organization of human groups in a given context and access a broad picture about their understanding of space, the Laboratory for Roman Provincial Archaeology (LARP) developed and released its virtual reality application called DOMUS by the end of 2013. DOMUS consists of a Pompeii-inspired Ancient Roman house that allows the user to navigate through its rooms, visualizing specific information such as the relevance of oil lamps, the religious cults and the local trading production of pottery. The DOMUS application was totally made by archaeologists, representing the pioneering effort of Brazilian researchers in producing the very first cyber-archaeological project in our country.

Combined with the use of technology, LARP's main academic efforts were concentrated in the promotion of discussions related to Roman Imperialism. Indeed the Romans took advantage of material production (coins, pottery, statues, monumental buildings, etc.) to justify their domination over the provinces, and we see how, through the represented images, the Romans sought to create policies of relations with the natives. On the other hand, we can also observe through the analysis of material culture that there was complete visibility of local elites and representativeness of local populations on these issues. The incessant political statement and/or opposition to Roman rule in the case of local populations and religious identity acts can be a remarkable aspect of this reality that we can approach through the material culture.

So, one has to consider the presence of each city's own deities within the material production from each province, analyzing the impressive ability of the Roman Empire to work ideologically with the cult of these deities and their representation in materiality; but one should consider local authorities' amazing cleverness in perceiving Rome's 'game' and participating in this project so as to make their and their people's culture prevail. Thus, the archaeological record has the potential to help us with the analysis of the strategies of the manipulation of identities in relation to materiality, politics and the economy (Jones 2007: 110). In this sense, when we take the DOMUS application and it is possible to perceived how comfortable and spacious were the houses of the Romans who belonged local elites compared with those dwellings of the representativeness of local populations who were living in Rome, if someone uses Roma 360 application.

Therefore, the Roman Empire was a multicultural and multi-religious society with complex ritualized forms of religious and social communication. Nevertheless, almost as a strike back, the Roman Empire increased its power and created several forms of ritualization for these local religions. Religion is a basic element of human organization in relation to their landscape and social affairs, and often, archaeological contexts are related to some sort of religious practice. The idea of religion is one of the first we receive within this life, and social organization comes with it during the formation of our lives. The same happens with spatial organization (if not the entire organization of space, in most cases) (Lefebvre 1974, De Certeau 1984). Thus, to some extent our sense of space is always debate on the knowledge of the cognitive process, especially 
when it comes to the manipulation of materiality and landscape by human groups. Exactly why is necessary to give priority to multidisciplinary approaches nowadays. With regard to the cognitive and meaning processes, the archaeological record can be addressed using various theoretical perspectives (including structuralism, cognitive semiotics, economic theory, Marxism, critical theory, among others). These perspectives help to foster interpretive possibilities and explanations of social difference and address more problematic questions regarding to the ability or power to return to the original form after being bent (resilience) and the power or capacity to opposing or retarding force (resistance). Without not forget about the problem of representation. The representation as experience brings the ability to produce meanings, and the adequacy of that is to be expressed and inserted in a cultural context (Geertz 1973: 105).

\section{Cyber-Archaeology and Local Elites}

In few words, we can explain Cyber-Archaeology as a dialogue between Archaeology and Virtual Reality. Differently from the 1980's Virtual Archaeology, the 2000's Cyber-Archaeology is not a passive process: the user does not only watch a rendered video, listening to the explications about what is seen on the screen - in the cyber-archaeological process, the user is part of the knowledge, being responsible for the development of cognition within the three-dimensional reconstruction. In that way, Cyber-Archaeology is necessarily interactive: it is the result of digital data gathered in the archaeological field, which is next analyzed by archaeologists into immersive environments (such as CAVEs or powerwalls) (Forte 2011: 7-10) and made available to the general audience later using less expensive interactive devices (such as smartphones, tablets and personal computers).

Cyber-archaeology studies have been conducted since the 2000s, when the archaeologist Maurizio Forte (Duke University) established the main premise of this new area: Cyber-Archaeology, as the name suggests, is fundamentally a cybernetic cycle - it starts with fieldwork and then continues to data/information collecting, interpretation, evaluation, feedback and, finally, embodiment (Forte 2010: 12-13). One of the most important researches on CyberArchaeology today is taking place at Çatalhöyük (Turkey). The Çatalhöyük Research Project ${ }^{2}$, conducted by Ian Hodder and Maurizio Forte, aims to digitally record each step of the archaeological digging. The archaeologists at laboratories study the huge amount of data in order to reconstruct threedimensionally the results from the fieldwork.

LARP's DOMUS application was developed aiming at the public in general, but with same principle idea (digitally record archaeological remains), mainly to offer as intuitive and interactive tool to teachers and students. From

${ }^{2}$ http://www.Catalhoyuk.Com. 
the study of the archaeological remains from Pompeii and Herculaneum, the researches established the major points that could be interesting to work with at classrooms by the teachers. Once chosen, we began the simultaneous process of writing the supporting texts and modeling the ancient domus (house). With each researcher being specialized in a particular Roman aspect, we were able to account for a wide range of subjects (from architecture to economics). For the 3D modeling, Autodesk Maya was used for every object while Unity engine was utilized to develop the interactivity. We opted to mix our texts with $3 \mathrm{D}$ objects in order to give complete information on each room that the user can visit from a first person point of view. Below, an example of DOMUS 3D Model (Figure 2).

\section{Figure 2. DOMUS 3D Model}

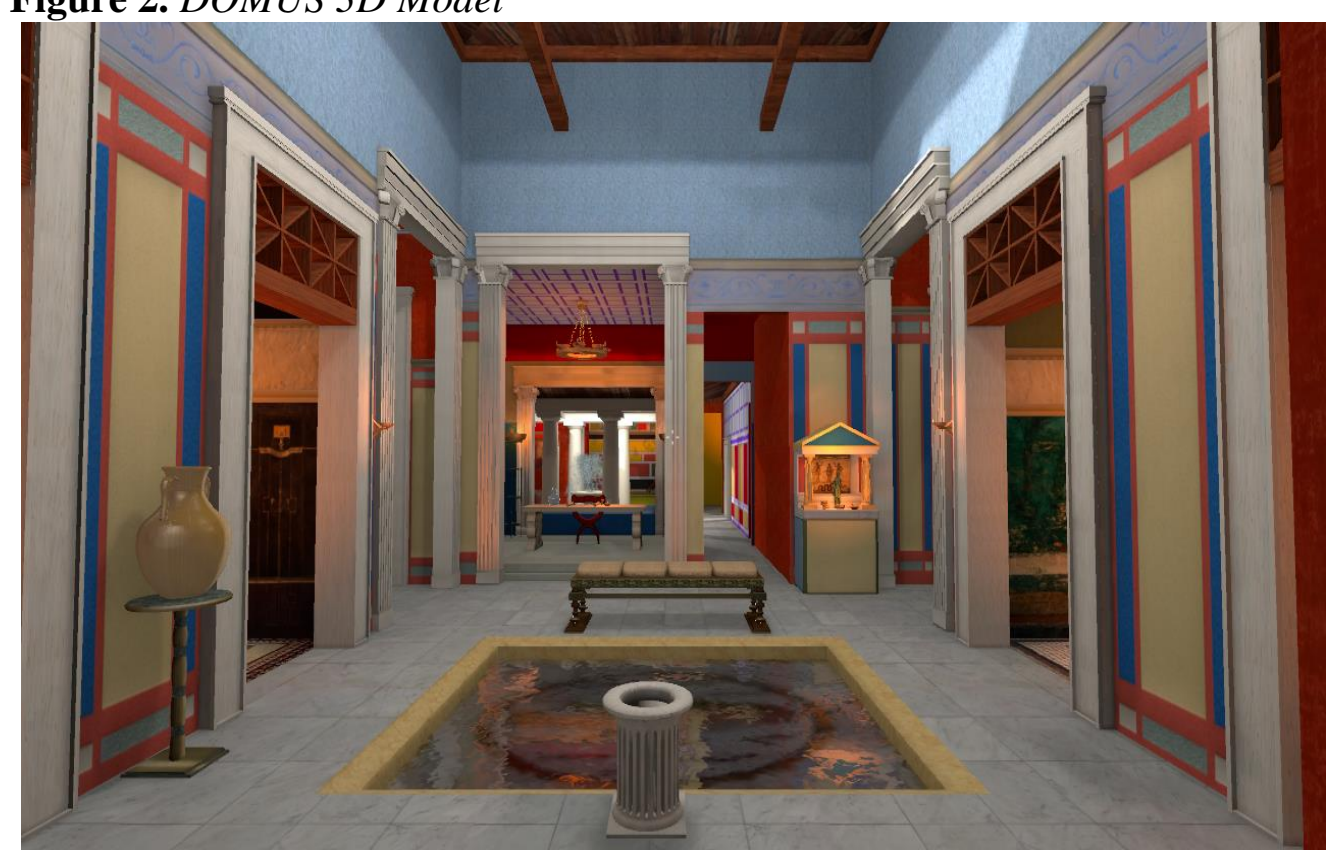

The objectives of DOMUS were defined as follows:

- Offer free navigation inside the house: allow the user to go where he/she wants without a pre-established script.

- Offer texts in accordance with the locality of the user: called texttriggers by the working group, these little information pieces form the succinct explanation for topics that are detailed in the supporting texts.

- Offer supporting texts: the application has a list of texts written by LARP researchers that deal with the following subjects: Roman domus, impluvium, balneum and latrine (researcher Alex dos Santos Almeida); tablinum and tavern (researcher Irmina Doneux Santos); lararium (researcher Tatiana Bina and Marcio Teixeira-Bastos); frescos (researcher Alessandro Mortaio Gregori); mosaics (researcher Silvana Trombetta); 
Vitruvius and architecture (Anisio Cândido Pereira Filho researcher); Roman economy (Professor Vagner Carvalheiro Porto - LARP's coordinator); oil lamps and Roman ceramics (Marcio Teixeira-Bastos and Professor Maria Isabel D'Agostino Fleming - LARP's coordinator). These texts were designed and written to provide extra material to use in the classroom as well as anyone who wants to know a bit more about the subject and use the supporting text as a starting point.

- Establish a comparison between the three-dimensional modeling and archaeological remains - through an Image Gallery, is offered the opportunity to compare the 3D reconstruction with photos of objects found in Roman houses and its traces.

- Have free and unrestricted online access - belonging to a public educational institution, the University of Sao Paulo, it is indisputable that all production should be reciprocated to the population free of charge. The best way to disseminate work these days is the Internet, allowing everyone to have the experience of walking into an interactive domus and deepen his or her knowledge with own bibliographic material.

Finishing the development of DOMUS, the application was exported to Web platform, making it able to be accessed online at the LARP website ${ }^{3}$ through HTML. The decision to make it available on the Internet reflects the lab's concern to make it accessible free of charge.

However, our original DOMUS application has proved to be too heavy for low-end desktop computers (machines without GPU). In our first attempt to apply it at schools, we faced the inconvenient problem of drop in frame rates, breaking the intended immersion in students. Computers at schools' laboratories usually are not equipped with off-board graphics cards, and the high number of polygons in the application turned our DOMUS practically pointless for the majority of schools, unfortunately.

After reconsidering our approach to educational purposes, we decided to reformulate the DOMUS application. This time, our main goal was to achieve the balance between aesthetics and functionality, optimizing the Ancient Roman house. To this end, we established the production of an Augmented Reality application. In Brazil, until then, no application of Augmented Reality had been produced in terms of Ancient History and Classical Archeology. The DOMUS A.R. (Augmented Reality) was LARP's first attempt at producing an augmented reality application (Figure 3). Thinking of offering to students and teachers the opportunity to work in small groups, the laboratory's first step was to develop the augmented reality marker.

\footnotetext{
${ }^{3} \mathrm{http} / / / \mathrm{www}$. larp.mae.usp.br/rv/.
} 
Figure 3. DOMUS A.R. Screenshot

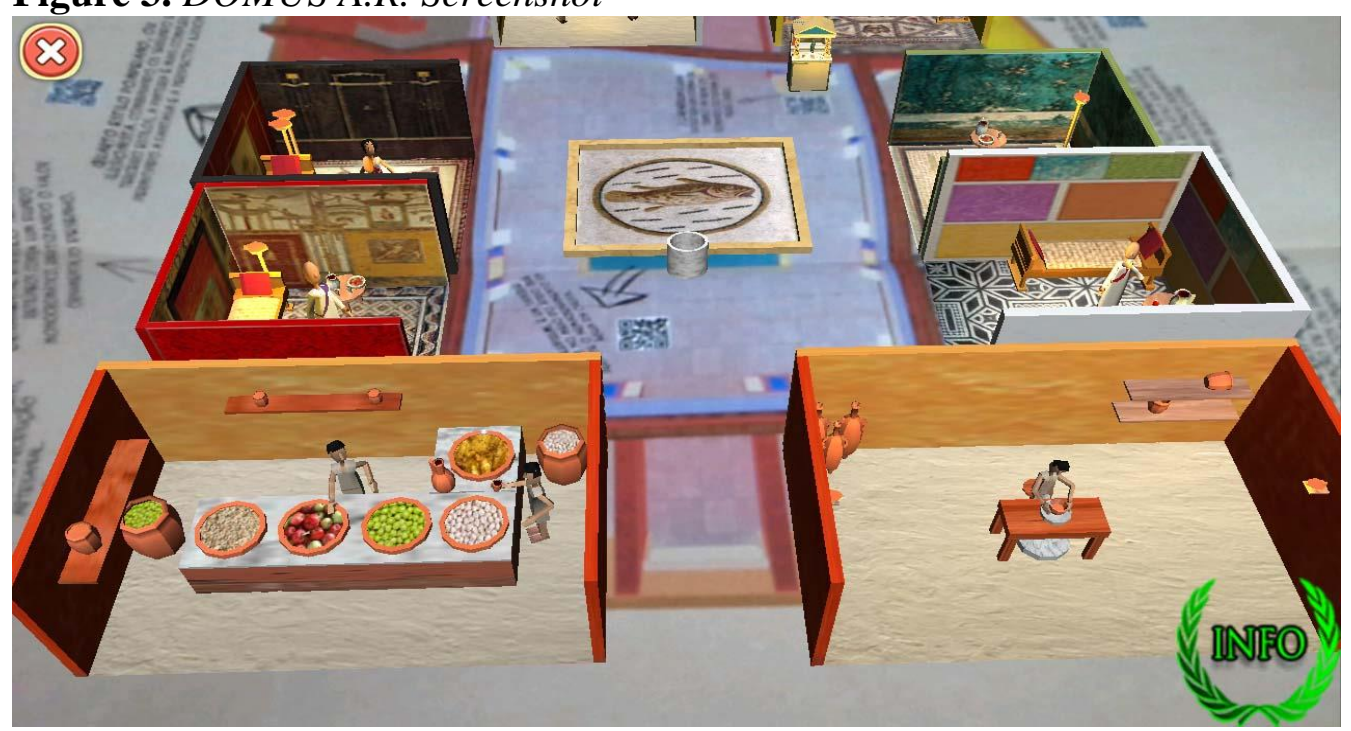

Since LARP is a thematic laboratory within a public university, all its products are based on its free distribution, seeking the broad dissemination of knowledge produced academically and decoded for the general public, teachers, and students. The examples of educational actions in schools have shown that students get more attached to the subject being able to establish a straight connection with the present living of their own (Figures 4 and 5). It's important highlight this aspect because (beyond the excitement for new tools and more accurate sense of ancient spaces) the students achieved a sense of representation - which means that were able to distinguish areas of activities (e.g. kitchen, shopping places, etc) and ask themselves, who were the people who worked in that place, and who are those people that were "only drinking wine laid down in the sofa", one said.

Figure 4. Teacher using DOMUS R.A. Application during Training provided by $L A R P$

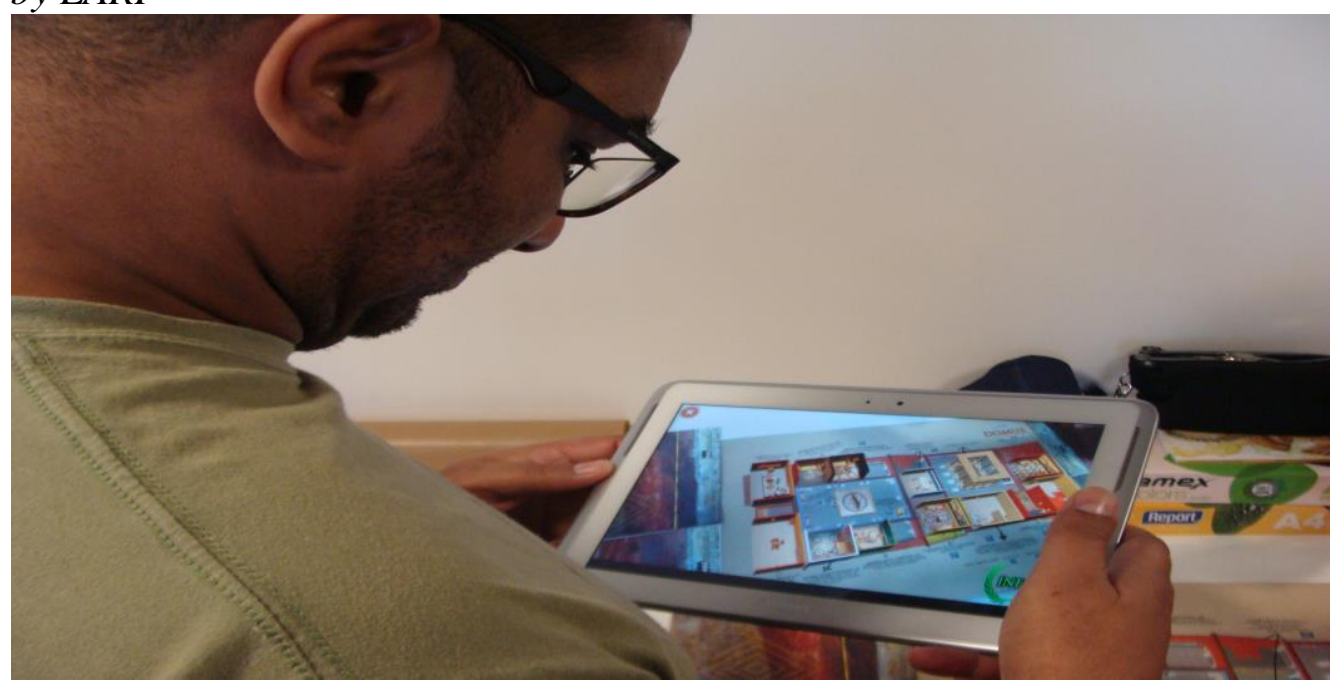


As archaeologists concerned with the significance of the use of space, resilience aspects and elite social behavior, we decided that the entire domus plan would be useful as a marker: the students could see the augmented reality while the teachers could give hints about the spatial those subjects, based on the printed marker.

Having the printed marker established, the application production process began. All the rooms were remodeled using Autodesk Maya. Being an augmented reality application for smartphones and tablets, the major concern was about the number of polygons to be displayed on the screen. Producing each room separately, we could reach a minimum number of vertices: each local consisted of three cubes (for the walls) and one plane (for the floor). In order to optimize the RAM consumption, all the textures were worked with the Adobe Photoshop software and then applied using just one UV map. For the very first time, we aggregated animated characters to our scene: a pair of Roman senators were modeled and animated with simple gestures, simulating conversations between them. Once all the objects were prepared, the complete scene was exported as a FBX file into the Unity engine.

Figure 5. Students working with DOMUS at School (Colégio Unidade Jardim Santo André. http://www.liceujardim.com.br)

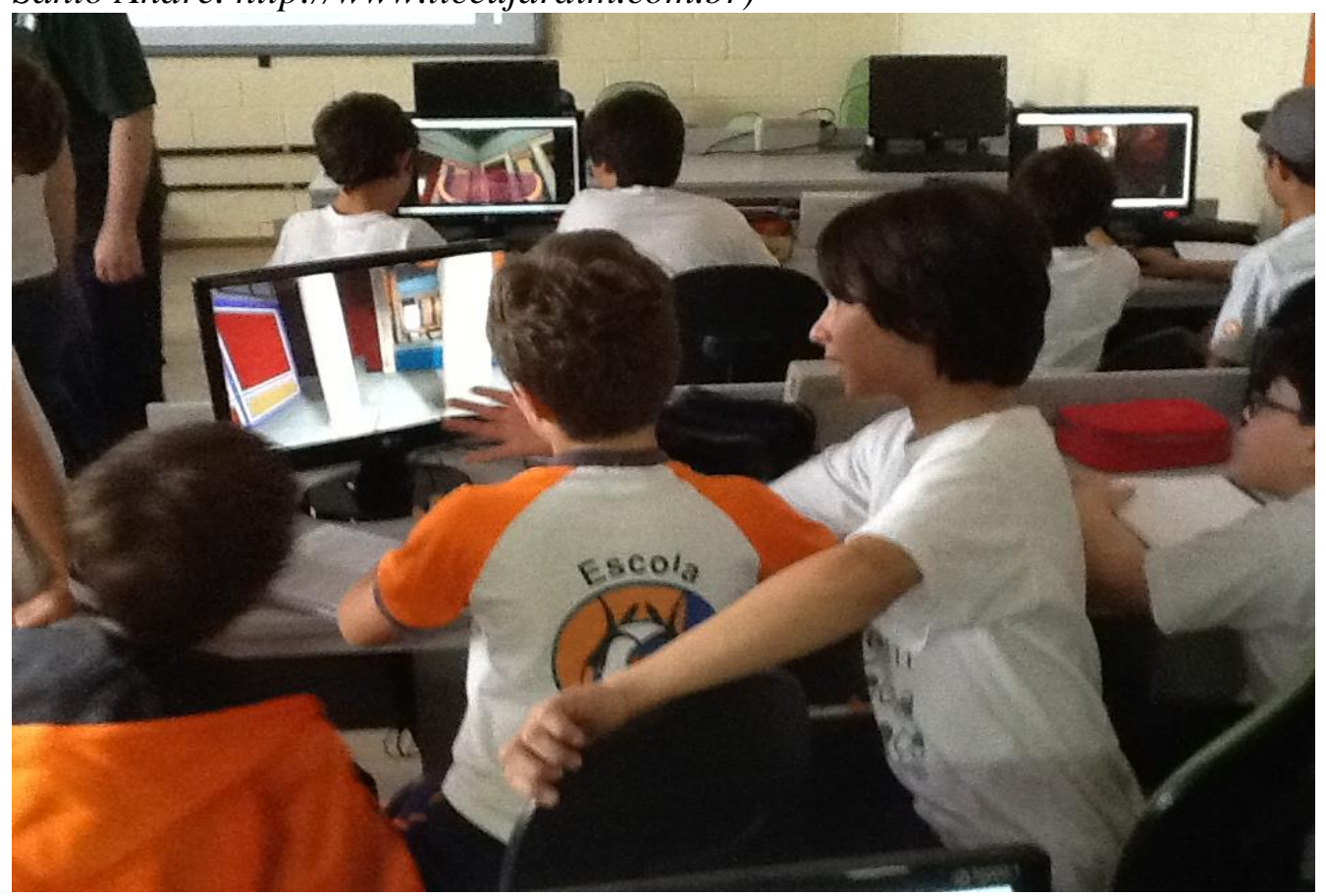

For the augmented reality interaction, the Qualcomm's Vuforia Unity extension was utilized. Making the programming easier, Vuforia allowed the simple drag and drop feature of the FBX files into Unity' scene. After the correct scaling and positioning of the models on the A.R. domus plan marker, we created the button to show the information about the rooms when pressed. In order to make our application even more complete, we modeled 3D additional resources (such as oil lamps, wine jars, coin and others) to be manipulated by 
the users through swipe and pinch gestures. Finished that stage, the application was built for the Android platform and distributed on our website (www.larp.mae.usp.br) and on Google Play free of charge. It is important to be a free pursue because in Brazil public schools (the vast majority in the country) do not have a budget to acquire software - that is a privilege for private schools only possess.

Also is important to note that the application of technological resources and the development of new didactic tools for Ancient History and Archaeology teaching do not offer to the teacher a miraculous alternative work or merely a stimulus in order that the student becomes interested in the school universe. It is a proposal designed to bring to schools more possibilities and resources for the student to appropriate a cultural heritage, reinvigorating the willingness to learn and promoting the collective construction of knowledge. The interaction, the discussion and the debate are favored and the teacher in this project is a mediator, an attentive observer of the formulations and inaccuracies or deficiencies of students: something very significant for understanding the reasoning and possible readings made by students about the past.

Essentially this recognition serves to assert that elite behavior implies an isolated category of practice or action. It is located in the cultural representations, the array of different discourses and practices that aim at the construction of the social world and the contradictory definition of identities.

\section{Representation and Identity: Religious Life Aspects and Roman Elite Be- havior}

In Rome, the elite continuously controlled religious behavior. The Roman elite defined what should be considered appropriate religious activity in the Imperial areas. Rome was never free for the exercise of all religions. The Roman elite, especially in the provinces, defined what was unsuitable for traditional Roman religion as a way to define their position within the State. Legal initiatives under the aegis of the defense of the Roman religious system were taken against real or imagined enemies, whenever they were within reach of the elite. Although they tolerated religious innovation amongst the subjugated peoples, foreign cults were often associated with mysteries and certain performances, associations and/or joint activities, which were not accepted, and were treated as religious crimes. The penalties for transgressions often involved public punishments. Religion was one of the major aspects of change with Rome and its Empire, which was configured as a federation of elites centered in the Mediterranean and its control interflow (Rizakis and Camia 2008).

Political identity was defined by access to religious rites, which coexisted with political rights within the Roman world. In a certain way, the individual only existed in the public dimension, to the extent that their subjectivity and inserted context allowed access to groups and their rites. In this sense, the equestrian order was much more amorphous and constantly more open to new members, not only in Italy but also in the provinces. During the reign of $\mathrm{Au}$ - 
gustus, the term 'religious' served to designate those who practiced the ritual according to the usual status (ritus romanum) and did not engage in superstitio. Categories of Religion and superstitio were not categorized as true or false, and are incorporated and used during the Christianization of the Empire campaign, institutionalized from the fourth century CE onwards. The term superstitio was initially used to categorize inappropriate behavior of individuals (not groups) in relation to the internal irregularities of the Roman rite. The term also referred to the meaning of powers and dangerous practices that the rite that could bring, such as some sort of threat to the stability of religion or of the Roman state (Beard et al. 1998: 213-215). Roman ritual traditions were one of the ways in which different people could be differentiated and characterized, as illustrated by the ritus compendium Graecus (Scheid 1995: 15-31).

From the Principality period, a number of direct measures were taken to control religious activities and associations of those outside the elite. Cesar Augusto banned private companies (collegia) fearing their social and political role of disorder. However, under Claudius was allowed a special dispensation for Jews, their collection of money, and its use for the Jewish community rather than imperial taxes. The ruling elite would, ordinarily, control communal meals in the organization of festivals, processions, purifications, sacrifices and do so in accordance with the calendar that evoked the Roman world. Saturnalia and Parentalia were cases where the celebrations took place in the household within the scope of domestic rites. However, public Roman rituals were more austere, and there were no sacred books, complex sentences or ceremonies whose meaning could be debated endlessly by scholars. In general, the sacrifice was more central to provincial Roman communities than it was in the metropolis (Elsner 1991: 50, Woolf 2009: 250). The gods who were honored with dedications by senators and equestrian officials who served in the provinces also reflect the traditional emphasis in the gods of Rome, especially Jupiter. By the fourth century $\mathrm{CE}$, senators and equestrian officials were rarely initiated into foreign services. Augusto strictly recommended that his son Gaius should not offer prayers to HaShem in Jerusalem. In fact, during the first century CE, the growth of "foreign superstitio" in Rome came to represent a threat to the official political-religious system.

Between the many Lares of Roman religion (Lares August, Lares Compitales, Lares Permarini, Lares Praestites, Lares Publici, Lares Viales) ${ }^{4}$ the Lares Familiaris, or the "Lares of the Family" were the protectors of the household and can be evidenced as the heart of private religious action and daily ritual behavior. The idea to emphasize the lararium at the entrance of LARP's DOMUS aims to perceive this private service as complementary to public services. In a sense, apart from the public worship practices in the temples, Roman religiosity was also expressed in the presence of the lararium con-

\footnotetext{
${ }^{4}$ Respectively "Lares of the Emperor","Lares of the Crossroads" (worshipped during the Compitalia), "Lares of the Sailors" (protectors of sailors), "Stand-By Lares" (protectors of the state), "Lares of the People" (also protectors of the state), "Lares of the Roads" (protectors of roads).
} 
tained in the Roman domiciles. The act of votive offerings to the gods, inviting them to the intimacy of the house, reflected in truth the primordial conception of the Pax Deorum, in which sharing the coexistence between human beings and gods is the essential premise. Therefore, the basic commitment of daily worship at home consisted in the separation of a "sacred place" at home, an altar or the lararium. On this altar both the Lares Familiaris - protective deities - and the deities of the paterfamilias were honored in two daily rites, one in the morning and the other at night. During these rites the gods are flattered and requests for protection, attention and prosperity were made. The lararium was a place where individuals could worship the gods confidentially, and yield small offerings. Essentially the lararium was the sacred place of the house, where the positive forces of the gods could be brought into existence of saecularis life.

The forms of the lararium is very varied, in residences of rich families could be located in the atrium, made of marble and reproducing aesthetically a temple, like a miniature copy. In other cases, in less affluent residences, it could be just a simple wooden shelf on the wall. Anyway, big or small, the important thing about a lararium altar is placed it in a central part of the house, where would not to be ignored or forgotten, nor in a place that obstructs the circulation. The main question, therefore, is that it should be a special place for the deities in the domestic and daily spheres. The composition of the lararium altar was made by seven elements: the pátera, the salinum, the turibulum, the acerra, the incensum, the gutus, and the lucerna (Figures 6 and 7).

Figure 6. DOMUS Lararium Screenshot

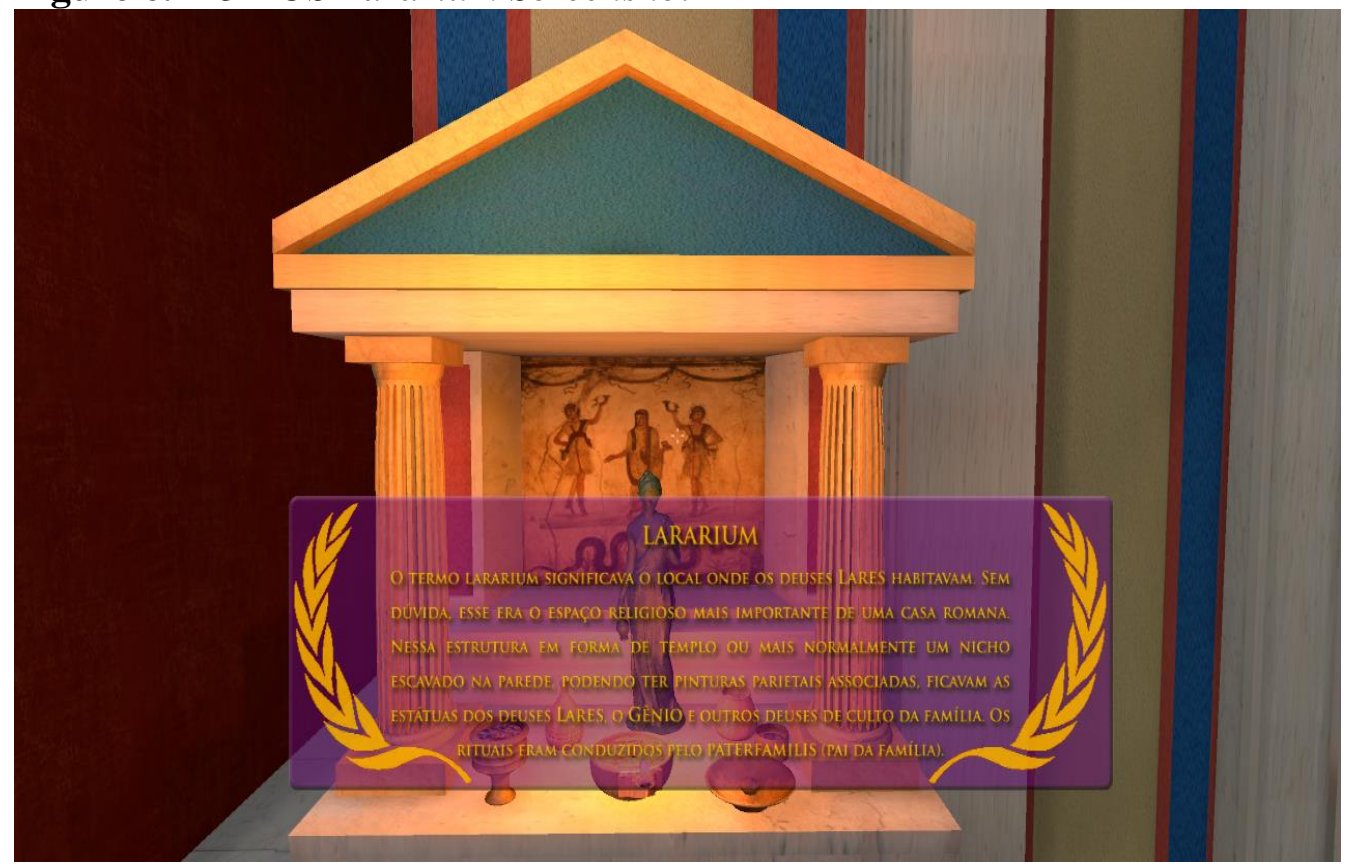




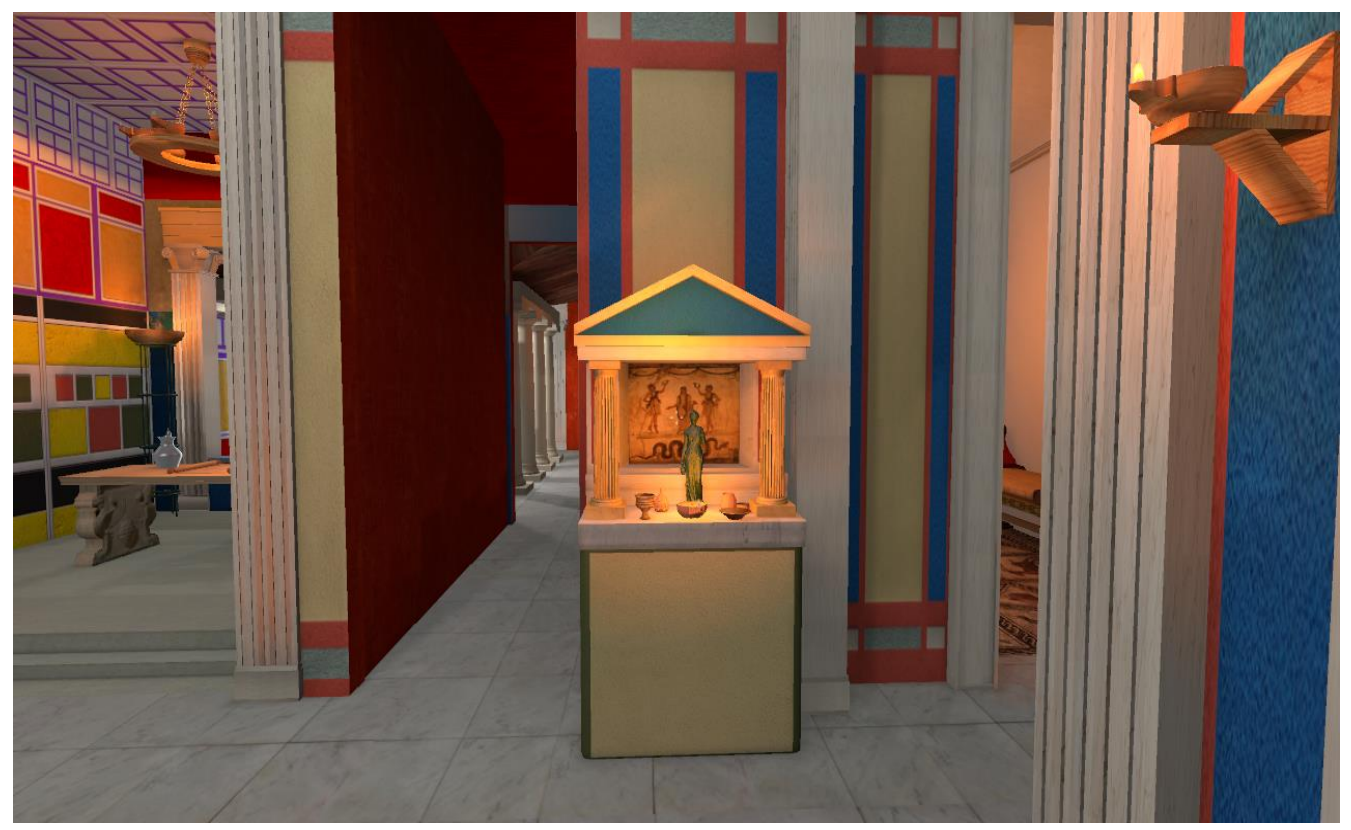

The pátera was a dish, generally shallow, in which a portion of the food of the house was offered as a way of sharing the supplied goodness in relation to everyday food. The salinum, in turn, was a container for salt that served the purpose of purifying the negative spirits. The turibulum was nothing more than a censer used to create the sacred scents that would satisfy the deities and could change things from the solid form to an ethereal form, consuming them with fire. This container contained hot coals and the powdered incense or aromatic resin that produced the aroma and votive smoke. Coals were also used to burn small offerings such as food portions, flowers or plants.

The accerra was a special vessel for the sacred incensum and a variety of incenses were used for those purposes in Roman society. Usually they were resins, substances or herbs sprayed, or even a mixture of the three. The resins as well as the incenses and mirras were very popular, being common the presence of such types of incensum in the lararium. The gutus consisted of a container for milk and/or the wine offered. Likewise the accerra and the salinum, the gutus were used to keep a substance offered clean and protected. While practically all previous containers were usually made of clay - and in some cases metal, depending on the preference and social position of the individuals - the gutus could be made of glass. The liquid of the gutus would be poured into the pátera when it was to be offered. It is important to say that all these foods offerings could not in any way remain a long period of time exposed, because they would certainly come to decompose. So it would be imperative to keep the offerings fresh, which implies a constant renewal of the votives offerings.

The last two other elements present in the lararium rites were: the sacred fire and the lucerna. It is through the lucerna, the oil lamp, that the representation of the source of the sacred flame was represented in the altar. An oil lamp should always be in the lararium and would usually be lit at the time of rites, 
which means, once in the morning and once in the evening, save private libations. The light in this context fulfills three essential roles: the first as the representation of the sacred flame, would open the precedent for the interpretation of the flame that produces, and the direction and oscillation of the flame could be interpreted as good or bad omen. The second aspect is of the representation of the image that would be depicted on the disc of the lucerna and could be associated with a certain votive purpose and/or a specific divinity. The third then, arising from both previous aspects - or even from the combination of both - would be the one of represents the material figuration of the communication between worlds. While the others offerings can be considered as the "voice of the offerer" - with the exception of the salinum that had a purifying role - the clay oil lamps would expresses both the "offerer's voice" and what we could call the "voice of the offered", regarding to the interpretation sings of the flame. Therefore, expresses communication between worlds present in the rituals of the lararium. The best examples of these worship/community-identity rituals come from working or craft class communities - elite homes/areas tend to be more eccentric and LARP's lately have work to modeled craft spaces and dwellings for comparison with elite homes.

\section{Figure 7. DOMUS Lararium Detailed Screenshot}

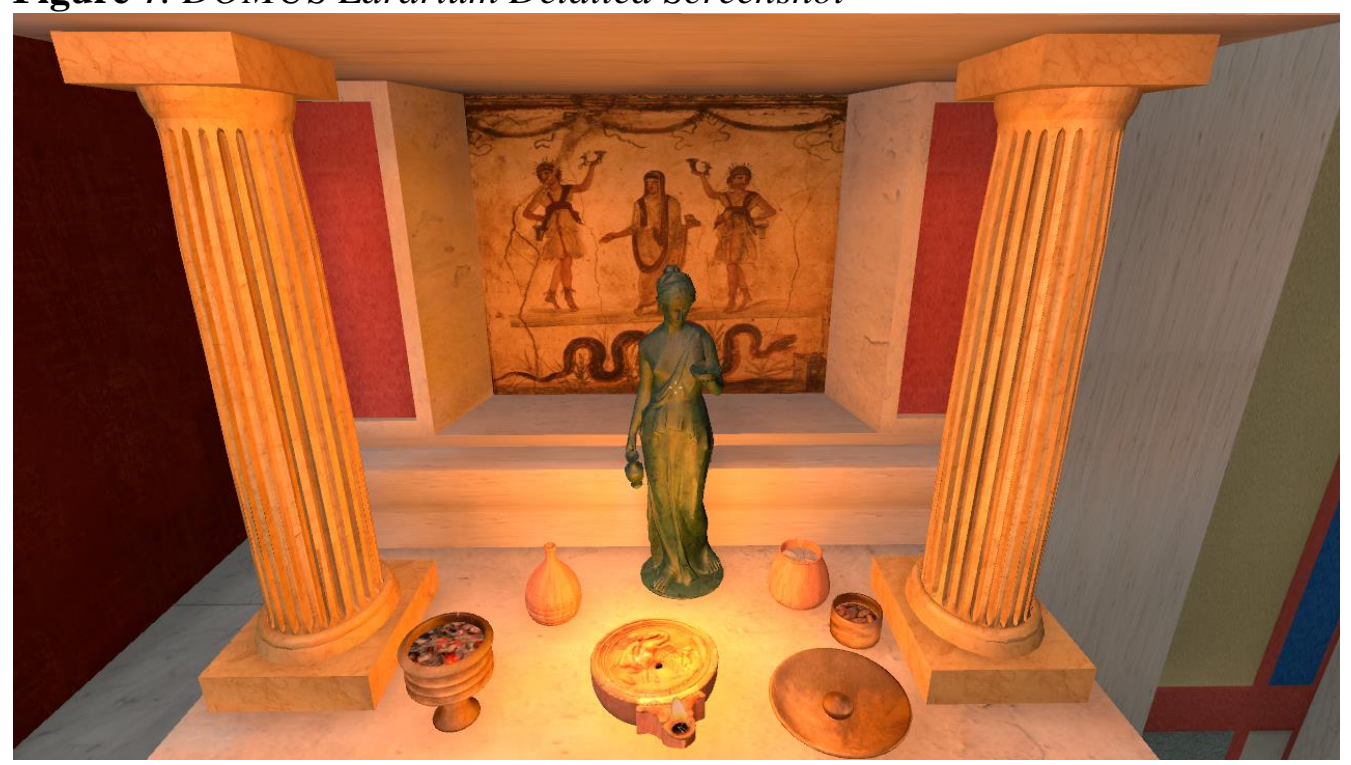

Beyond the private services, there is a broad consensus that public services in Orbis Romanorum were at the center of the practice of Roman religion. The concentration of public services in the cities shows that Roman religion in the provinces held similar characteristics to that practiced in the metropolis, especially between the local elites. However, the priesthood of the provincial pontiffs did not seem to be organized in the form of court, at least not in the way their peers did it in the metropolis. Roman priesthood in provincial communities appears to have been more involved with the ritual performance than in Rome itself (Woolf 2009: 244). 
In this sense, Roman imperial cult has been understood as a set of rituals designed to integrate the emperor at the local pantheon in order to grant favors and provincial loyalty. It is indicative that the increased power of ritualization in the Roman Empire was a consequence of the slow shift that occurred in the understanding of the ideal of Civilis Princes. In other words, between the traditional ideal of equality of all Roman citizens and the new imperial quality of distance and elevation, which led to the understanding of the emperor as a protector of the traditions, and divine arbiter, of the religion and romanum rituale (Silva 2003). In this sense, the emperor is the one who can intervene and control the sacer (sacred), which refers to what was "dedicated to a deity" in the Roman habitus (Bourdieu 1996). This embraces both the understanding of places and objects, such as that people provide the primary functions of religion (and their rituals) precisely because they provide mechanisms to define where secular life ends and religious life begins.

Therefore, political and religious aspects of life helped to forge distinctive ways of being in society during Roman domination. These aspects are still on play nowadays. Thus, combine digital tools to approach those subjects is worthwhile to foster new thoughts about how ancient people could have had managed their social power or capacity to oppose and/or retarding Roman forces within this "Roman way of life".

\section{References}

Beard M, North J, Price S (1998) Religions of Rome. Vol I - A History. Cambridge: Cambridge University Press.

Bourdieu P (1996) Razões Práticas: Sobre a Teoria da Ação. [Practical Reason: On the Theory of Action.] Campinas: Ed. Papirus.

De Certau M (1984) The Practice of Everyday Life. Translated by Steven Rendall, Berkeley: University of California Press.

Elsner J (1991) Cult and sculpture: Sacrifice in the Ara Pacis Augustae. The Journal of Roman Studies 81: 50-61.

Geertz C (1973) The Interpretation of Cultures. New York: Basic Books, Inc., Publishers.

Forte M (ed) (2010) Cyber-Archaeology. Oxford: Archaeopress, BAR (2177): 9-13.

Forte M (2011) Cyber-Archaeology: notes on the simulation of the past. Virtual Archaeology Review (VAR) 2(4): 7-18.

Jones A (2007) Memory and Material Culture. Cambridge: Cambridge University Press.

Lefebvre H (1974) From the Production of Space. Trans. Donald Nicholson-Smith. Cambridge, Blackwell, 1991.

Rizakis AD, Camia F (eds) (2008) Pathways to Power: Civic Elites in the Eastern Part of the Roman Empire (Proceedings of an international conference held at the Italian Archaeological School at Athens, December 19, 2005) (Tripodes 6), Athens: 23-41.

Scheid J (1995) Graeco ritu: a typically Roman Way of Honoring the Gods, HSCP 97, 1531.

Silva GV (2003) Reis, Santos e Feiticeiros: Constâncio II e os Fundamentos Místicos da Basileia [Kings, Saints and Sorcerers: Constantius II and the Mystical Foundations of Basel] (337-361), 1ed. Vitória: Edfus. 
Woolf G (2009) Word religion and world empire in the Ancient Mediterranean. In F Fabricius 2009 Die Religion des Imperium Romanum [The Religion of the Roman Empire ]. Koine und Knfrontationen. Tübingen: Mohr Siebeck. 
